\title{
APLIKASI PEMANFAATAN LIMBAH JAMBU BIJI MENJADI MOL SEBAGAI BIOAKTIVATOR PENGOLAHAN SAMPAH ORGANIK DI DESA PANYINGKIRAN
}

\author{
Dini Widianingrum*, Oki Imanudin, Abdul Kholik \\ Universitas Majalengka, Indonesia \\ *diniwidianingrum@unma.ac.id
}

\begin{abstract}
Panyingkiran Village, Panyingkiran District, Majalengka Regency is a red guava producing center. Red guava waste is leftover or rejected from the sale of red guava because it is bruised, rotten, overripe, and has caterpillars. Red guava waste consists of flesh and fruit seeds. If left unchecked, it will cause environmental pollution, invite flies, have an unpleasant odor, causing respiratory problems for the community. This is very detrimental to the community so that red guava waste must be used, among others, as MOL (local microorganism) which functions as a bioactivator for processing organic waste. The purpose of making red guava MOL is to utilize red guava waste into MOL, to get a bioactivator to process organic waste so as to create a healthy, clean, and zero waste community environment. The extension method used in the application of making MOL from red guava is carried out in demonstration plots and continuous guidance to youth groups, communities, collectors and guava farmers in Panyingkiran Village for 20 days through meetings, discussions, and the practice of making MOL. The results obtained good MOL of red guava with the following physical characteristics: blackish brown color, MOL characteristic aroma, liquid form, not moldy, and does not smell bad. In conclusion, red guava waste is good to be used as MOL as a bioactivator for processing organic waste.
\end{abstract}

Keywords: red guava waste; MOL; bioactivator

\begin{abstract}
Abstrak
Desa Panyingkiran Kecamatan Panyingkiran Kabupaten Majalengka merupakan sentra penghasil jambu biji merah. Limbah jambu biji merah merupakan sisa atau afkiran dari penjualan jambu biji merah karena memar, busuk, terlalu matang, ada ulatnya. Limbah jambu biji merah terdiri atas daging dan biji buah. Apabila dibiarkan akan menimbulkan polusi lingkungan, mengundang lalat, adanya bau yang tidak sedap, sehingga menimbulkan gangguan pernafasan bagi masyarakat. Hal ini sangat merugikan bagi masyarakat sehingga limbah jambu biji merah harus dimanfaatkan antara lain dijadikan MOL (mikroorganisme local) yang berfungsi sebagai bioaktivator pengolahan sampah organic. Tujuan pembuatan MOL jambu biji merah yaitu untuk pemanfaatan limbah jambu biji merah menjadi MOL, mendapatkan bioaktivator untuk mengolah sampah organic sehingga tercipta lingkungan masyarakat yang sehat, bersih, dan zero waste. Metode penyuluhan yang digunakan pada aplikasi pembuatan MOL dari jambu biji merah dilaksanakan secara demplot dan pembinaan yang terus menerus kepada karang taruna, masyarakat, pengepul dan petani jambu di Desa Panyingkiran selama 20 hari melalui pertemuan, diskusi, dan praktek pembuatan MOL. Hasilnya diperoleh MOL jambu biji merah yang baik dengan ciri fisik sebagai berikut warna coklat kehitaman, aroma khas MOL, berbentuk cair, tidak berjamur, dan tidak bau busuk. Kesimpulannya limbah jambu biji merah baik dijadikan MOL sebagai bioaktivator pengolahan sampah organic.
\end{abstract}

Kata Kunci: limbah jambu biji merah; MOL; bioaktivator

\begin{tabular}{l|l|l} 
Submitted: $2021-09-23$ & Revised: 2021-10-26 & Accepted: 2021-10-30
\end{tabular}

\section{Pendahuluan}

Jambu biji merah (Psidium guajava L.) merupakan buah lokal banyak terdapat di Kabupaten Majalengka. Sentra daerah penghasil jambu biji antara lain Kecamatan Panyingkiran dan Kecamatan Salagedang. Produksi jambu biji merah Kabupaten Majalengka sebanyak 5.034 ton dan limbahnya sebanyak 41,5 ton (Widianingrum et al., 2019). Limbah jambu biji merah merupakan sisa atau afkiran dari penjualan jambu biji merah dengan alasan pengafkiran karena memar, terlalu matang, ada ulatnya. Limbah jambu biji merah terdiri atas daging dan biji buah (Padang \& Maliku, 2019).

Tanaman jambu biji merah merupakan salah satu tanaman buah yang banyak ditemukan di wilayah Indonesia, walaupun sebenarnya berasal dari Amerika Tropik. Tanaman ini berbuah sepanjang tahun, sering tumbuh liar, dan umumnya ditemukan pada ketinggian 1-1200 m dpl, 
serta tumbuh dengan baik pada tanah yang gembur maupun liat. Jambu biji secara taksonomi tergolong ke dalam famili Myrtaceae, genus Psidium, spesies guajava, sehingga dàlam bahasa Latin disebut Psidium guajava L. Dalam bahasa Inggris jambu biji dikenal sebagai guava, sedangkan di Indonesia disebut juga jambu batu, jambu klutuk, atau jambu Siki (Rusdi, 2020).

Jambu biji merah merupakan buah yang istimewa yang memiliki kandungan nutrisi yang cukup lengkap, seperti vitamin C, potasium, dan besi. Selain itu, juga kaya feed non gizi, seperti serat pangan, komponen karotenoid, dan polifenol. Buah jambu biji merah bebas dari asam lemak jenuh dan sodium, rendah lemak dan energi, tetapi tinggi akan serat pangan (Rahayuningrum \& Morika, 2019).

Limbah jambu biji merah merupakan daging dan biji jambu yang mempunyai vitamin $\mathrm{C}$ cukup tinggi karena berasal dari jambu yang diafkir yang tidak memenuhi kualitas persyaratan yang ditetapkan seperti ukuran terlalu kecil, rusak dan terlalu matang (Aristanti \& Widyastuti, 2016). Kandungan nutrisinya sama dengan jambu yang utuh yaitu energi 49 kalori, protein 0,90 gram, lemak 0,30 gram, karbohidrat 12,20 gram, vitamin A 25 SI dan vitamin C $87 \mathrm{mg}$ (Diana et al., 2019). Kandungan vitamin yang cukup tinggi merupakan sumber antioksidan yang baik. Selain itu jambu biji merah juga mengandung senyawa eugenol yang baik untuk memperbaiki kualitas produksi, sebagai bioaktivator dalam fermentasi atau pengomposan sampah organic (Imanudin \& Widianingrum, 2018).

MOL adalah mikroorganisme local yang dimanfaatkan sebagai starter dalam pembuatan limbah organik padat maupun cair (Kurniawan, 2018). Bahan utama MOL terdiri dari beberapa komponen yaitu karbohidrat, glukosa, dan sumber mikroorganisme. Bahan dasar untuk fermentasi larutan MOL dapat berasal dari hasil pertanian, perkebunan, maupun limbah organik rumah tangga(Imanudin \& Widianingrum, 2018). Karbohidrat sebagai sumber nutrisi untuk mikroorganisme dapat diperoleh dari limbah organik seperti jambu biji air cucian beras, singkong, gandum, rumput gajah, dan daun gamal. Sumber glukosa berasal dari cairan gula merah, gula pasir, sebagai sumber energi, air kelapa dan urin sapi sebagai sumber mikroorganisme (Widianingrum et al., 2019).

Larutan MOL yang telah mengalami proses fermentasi dapat digunakan sebagai dekomposer dan pupuk cair untuk meningkatkan kesuburan tanah dan sumber unsur hara bagi pertumbuhan tanaman (Handayani, S. H., Yunus, A., Susilowati, 2015). Mikroorganisme merupakan makhluk hidup yang sangat kecil, mikroorganisme digolongkan ke dalam golongan protista yang terdiri dari bakteri, fungi, protozoa, dan algae (Wisnu, 2020).

Tujuan dari kegiatan ini yaitu memberikan penyuluhan dan pelatihan kepada petani, pengepul, pedagang jambu biji merah, dan masyarakat mengenai aplikasi pemanfaatan limbah jambu biji merah menjadi MOL sebagai bioaktivator pengolahan sampah organic. sehingga diharapkan dapat memberikan keterampilan dan dapat meningkatkan penghasilan tambahan bagi keluarga melalui MOL sebagai bioaktivator dan kompos yang dihasilkan. Selain itu dapat terciptanya kondisi kebun jambu yang bersih, sehat, dan ramah lingkungan.

\section{Metode}

Metode Pelaksanaan kegiatan ini dilakukan dengan cara mengkoordinasikan terlebih dahulu dengan Kepala Desa Panyingkiran terkait teknis dimana akan dilaksanakan kegiatan pelatihan ini. Kegiatan dilakukan di balai Desa Panyingkiran Kecamatan Panyingkiran Kabupaten Majalengka. Sebelum penyuluhan dilaksanakan, dilakukan Pre-Test kepada masyarakat sebagai peserta penyuluhan terlebih dahulu. Setelah itu, dilakukan penyuluhan dengan metoda ceramah tentang potensi jambu biji merah, keadaan lingkungan, dan materi mengenai pemanfaatan limbah jambu biji merah yang digunakan menjadi MOL sebagai bioaktivator dalam pengolahan sampah organic. 
Kemudian dilakukan demonstrasi cara serta diskusi mengenai pembuatan MOL dan kegiatan diakhiri dengan Post-Test.

Pembuatan MOL jambu biji merah sesuai petunjuk (Widianingrum et al., 2019):

1. Bahan antara lain limbah jambu biji, terasi matang instan, 1,5 liter urine sapi/air kelapa, $1 \mathrm{~kg}$ gula merah iris tipis, Air 1 liter, Botol aqua 2 liter, Air 1 liter. Alat yang digunakan antara lain Jerigen plastic kapasitas 10 liter, selang plastic 1,5meter, blender (alat penumbuk), baskom plastic besar, panci, kompor, sendok, saringan, dan selotip.

2. Prosedur pembuatan yaitu membersihkan limbah jambu biji dari kotoran, menghancurkan limbah jambu biji dengan cara diblender atau ditumbuk halus, merebus air dan menambahkan irisan gula merah sampai mendidih, lalu dinginkan, mencampurkan limbah jambu biji, terasi, urin sapi/air kelapa, dan gula dan masukkan ke dalam jerigen, serta menyimpan jerigen di atas kursi, mengisi botol aqua dengan air 1 liter, menghubungkan jerigen dan botol aqua dengan menggunakan selang plastic, menjaga instalasi mol agar tetap anaerob dengan cara menutup (selotip) sambungan jerigen dengan selang, dan botol dengan selang, agar udara tidak keluar masuk, menyimpan larutan dalam tong plastik tertutup selama 2 minggu.

\section{Hasil dan Pembahasan}

1. Kegiatan Penyuluhan, diskusi, dan Demplot

Kegiatan aplikasi pemanfaatan limbah jambu biji merah dapat dilaksanakan dengan baik. Diawali dengan pembukaan dan sambutan Kepala Desa Panyingkiran yang menyambut baik adanya kegiatan ini, dilanjutkan dengan harapan agar masyarakat terutama karang taruna dapat benar-benar mengerti, memahami, dan dapat melaksanakan pembuatan MOL dari limbah jambu biji merah ini dengan baik.

Tujuan dari kegiatan ini yaitu memberikan penyuluhan dan pelatihan kepada petani, pengepul, pedagang jambu biji merah, dan masyarakat mengenai aplikasi pemanfaatan limbah jambu biji merah menjadi MOL sebagai bioaktivator pengolahan sampah organic. sehingga diharapkan dapat memberikan keterampilan dan dapat meningkatkan penghasilan tambahan bagi keluarga melalui MOL sebagai bioaktivator dan kompos yang dihasilkan. Selain itu dapat terciptanya kondisi kebun jambu yang bersih, sehat, dan ramah lingkungan.

Bimbingan teknis pengolahan limbah jambu biji merah. Penyuluhan dilaksanakan dengan cara pendampingan dan pengarahan serta bimbingan teknis mengenai prosedur pengolahan limbah jambu biji merah menjadi MOL sebagai bioaktivator, sebagai berikut: Memberikan penjelasan tentang keunggulan dan kekurangan jambu biji merah, pentingnya memilih dan memilah sampah organic dan anorganik, sampah organic yang telah dikumpulkan kemudian dihomogenkan dan dicampur dengan bahan lain, kemudian masukan kedalam karung. Selanjutnya membuat larutan MOL sebagai bioaktivator dalam jerigen yang terdiri dari: limbah jambu biji merah $3 \mathrm{~kg}$, gula merah $1 / 2 \mathrm{~kg}$, urine sapi atau air cucian beras atau air kelapa, dan terasi, tutup rapat selama 7-14 hari (fermentasi), bila sudah matang MOL sebagai bioaktivator memiliki bau masam (menyerupai bau tapai/peuyeum) dan MOL sebagai bioaktivator siap digunakan sebagai starter dalam pengolahan dan pengomposan limbah organik. Pembuatan MOL sebagai bioaktivator dengan memanfaatkan limbah jambu biji merah berisi tentang ceramah, praktek dan demontrasi pembuatak MOL jambu ceramah tentang jambu biji merah, serta diskusi. 

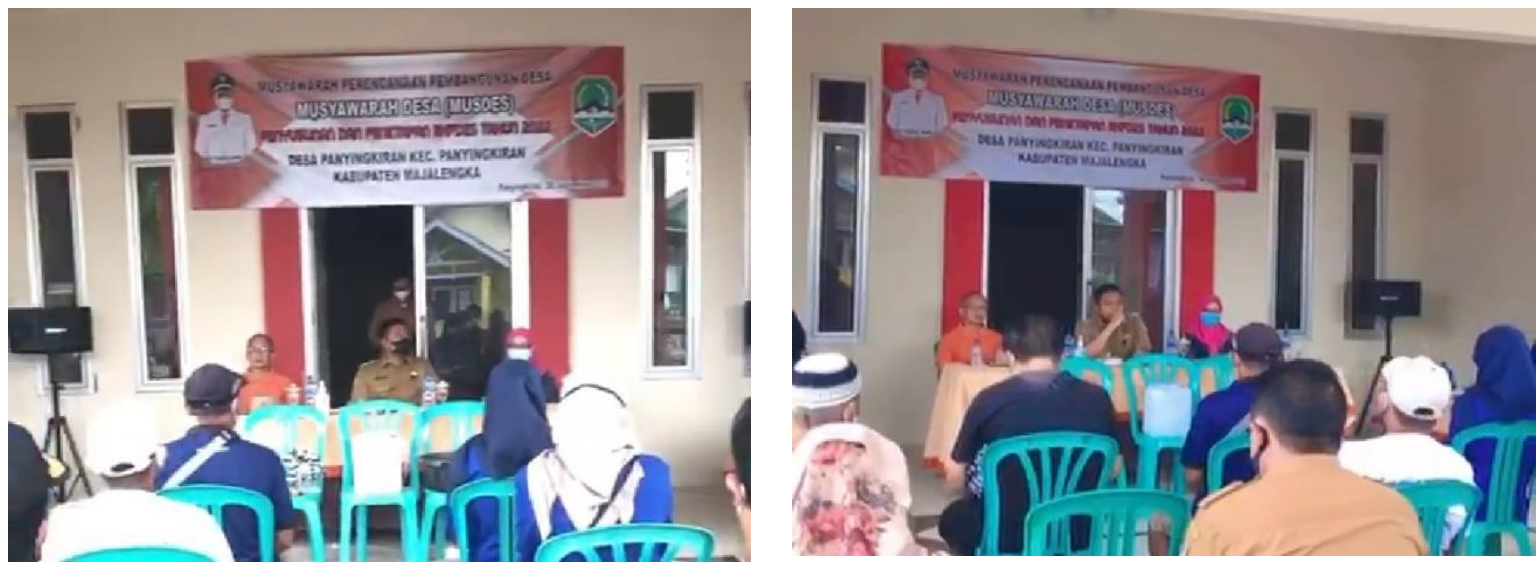

Gambar 1. Sambutan Kepala Desa Panyingkiran
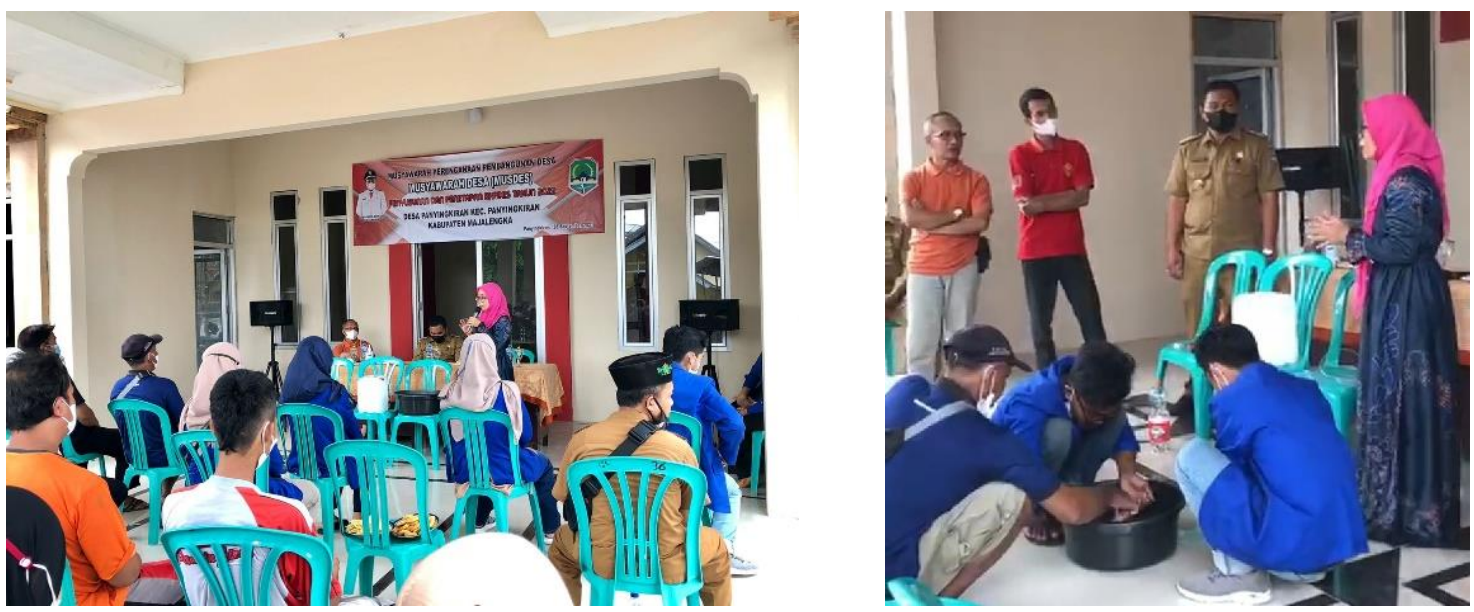

Gambar 2. Ceramah dan Diskusi Pembuatan MOL Limbah Jambu Biji Merah
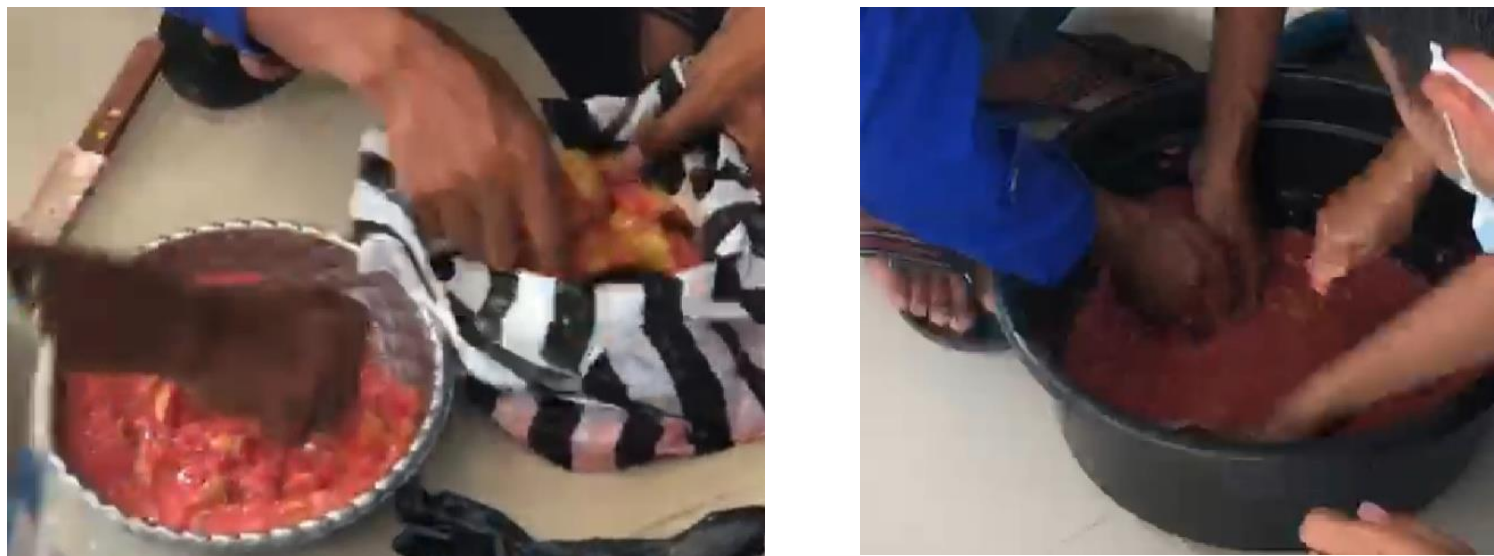

Gambar 3. Homogenisasi Limbah Jambu Biji Merah, Gula Merah, Air Kelapa, dan Terasi 

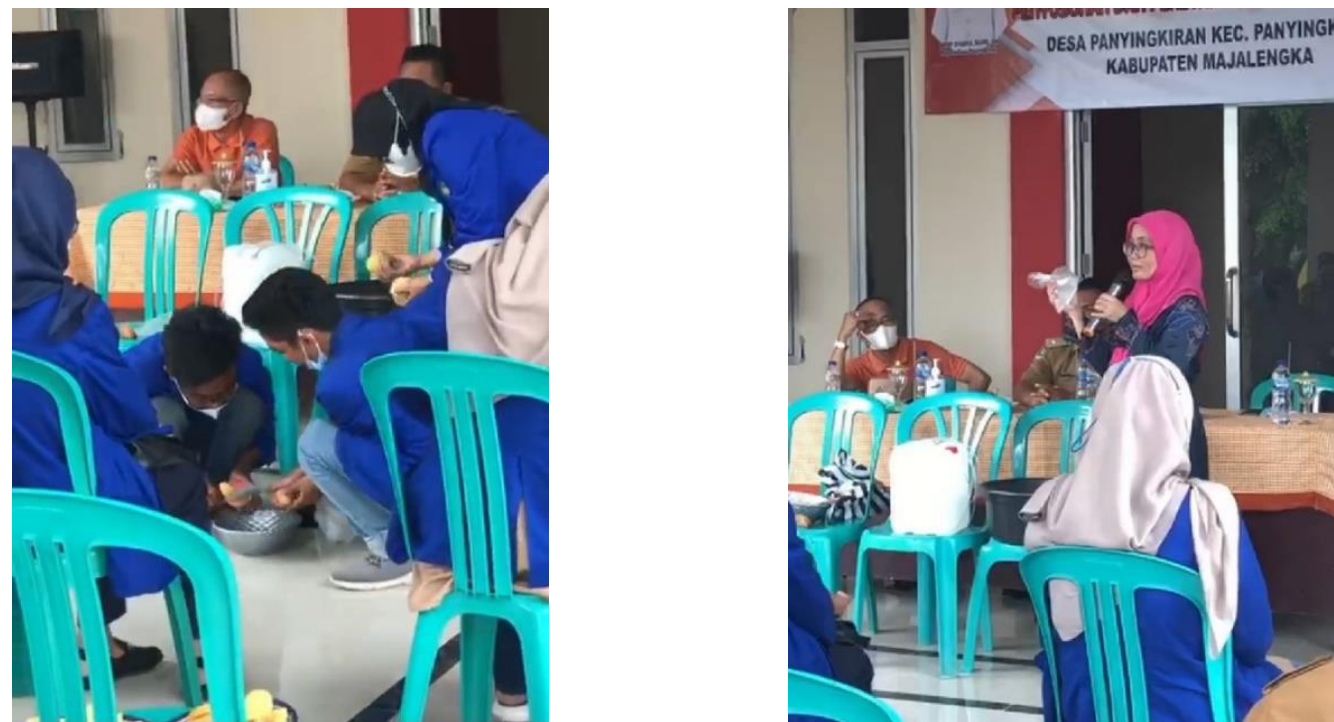

Gambar 4. Diskusi Alat dan Bahan yang Digunakan
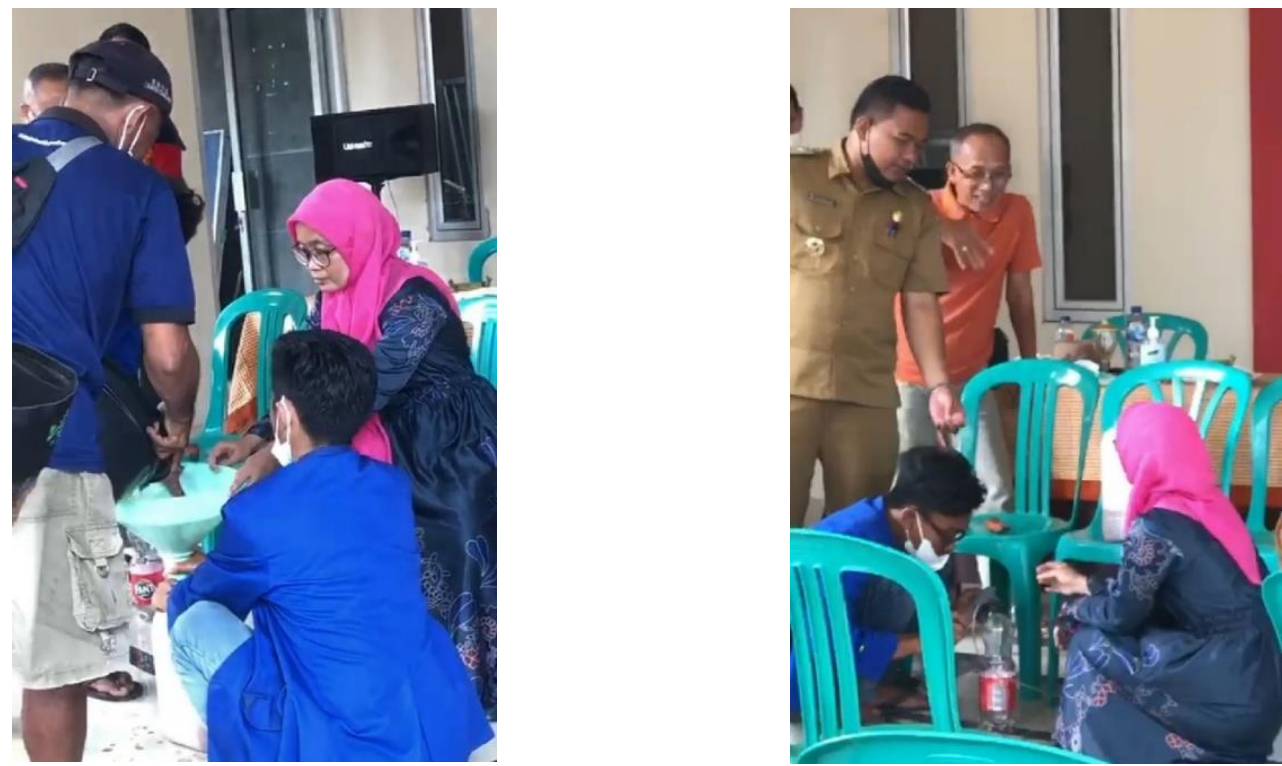

Gambar 5. Proses Pemasukan dan Fermentasi Larutan MOL Limbah Jambu Biji Merah
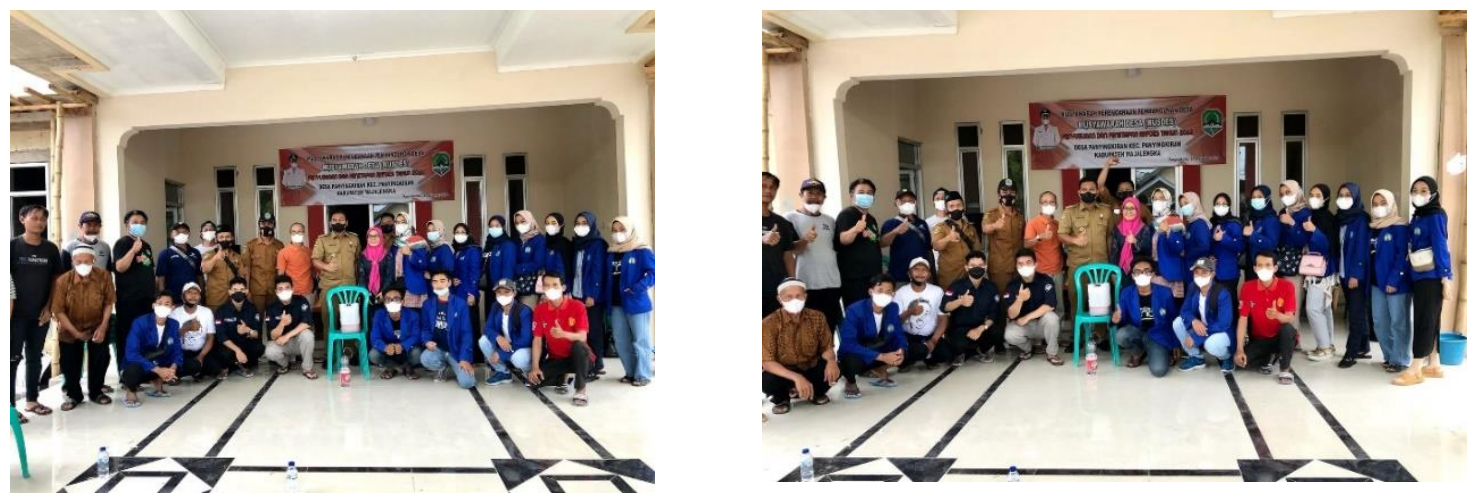

Gambar 6. Jerigen Larutan MOL dan Peserta Pembuatan MOL Limbah Jambu Biji Merah 
Bahan organik memiliki peranan penting sebagai sumber karbon, dalam pengertian luas sebagai sumber pakan, dan juga sebagai sumber energi untuk mendukung kehidupan dan berkembangbiaknya berbagai jenis mikroorganisme tanah (Sultoni et al., 2019). Penurunan kandungan bahan organik tanah menyebabkan mikroorganisme dalam tanah mengalami kekurangan(Hadi, 2019).

Larutan MOL adalah hasil larutan fermentasi yang berbahan dasar dari sumber daya yang tersedia, mengandung unsur hara makro dan mikro mengandung mikroorganisme berpotensi sebagai perombak bahan organik, perangsang pertumbuhan dan agen pengendali hama dan 7 penyakit tanaman sehingga baik digunakan sebagai dekomposer, pupuk hayati, dan pestisida organik (Gandu et al., 2021). Larutan MOL harus mempunyai kualitas yang baik sehingga mampu meningkatkan kesuburan tanah, dan pertumbuhan tanaman secara berkelanjutan. Kualitas merupakan tingkat yang menunjukkan serangkaian karakteristik yang melekat dan memenuhi ukuran tertentu. Faktor- faktor yang menentukan kualitas larutan MOL antara lain media fermentasi, kadar bahan baku atau substrat, bentuk dan sifat mikroorganisme yang aktif di dalam proses fermentasi, pH, temperatur, lama fermentasi, dan rasio $\mathrm{C} / \mathrm{N}$ dalam bahan (Jumali, 2017).

\section{Evaluasi Pengetahuan Peserta}

Evaluasi Pengetahuan Peserta Test awal (Pre-Test) dilakukan sebelum kegiatan penyuluhan pertanian yang dilaksanakan 7 hari sebelum pelaksanaan penyuluhan. Adapun tujuan pelaksanaan Test awal (Pre- Test) adalah untuk mengetahui tingkat pengetahuan masyarakat dalam pengaplikasian bioaktivator dalam rekayasa pengolahan sampah organic. Jumlah responden dalam tes awal (Pre-Test) adalah 30 orang dengan jumlah pernyataan sebanyak 20 pertanyaan. Test akhir (Pre-Test) dilakukan setelah kegiatan penyuluhan hal ini dilakukan untuk mengetahui pengetahuan masyarakat dalam mengaplikasikan bioaktivator asal limbah jambu biji merah dalam pengolahan sampah organic menjadi kompos serta dapat menjaga lingkungan dan meningkatkan sanitasi lingkungan.

Dalam pelaksanaan evaluasi terdapat 30 orang dengan jumlah pernyataan sebanyak 20 pertanyaan. Nilai hasil evaluasi saat Pre_Test adalah 1356. sedangkan nilai Post- Test mencapai 1554, sehingga terjadi peningkatan pengetahuan peternak setelah dilaksanakan penyuluhan sebesar 198.

\section{Monitoring dan Evaluasi}

Monitoring dan evaluasi dilakukan secara berkala pada setiap proses kegiatan. Pada saat monitoring diuraikan tentang proses yang terjadi serta kegagalan dan hambatan yang terjadi disebabkan oleh berbagai faktor. Berbagai solusi dan pencegahan kegagalan didiskusikan dengan para peserta penyuluhan.

\section{Persepsi Peserta}

Setelah mengikuti kegiatan ini peserta pelatihan yang terdiri atas petani, pengepul, dan pedagang jambu biji merah, serta masyarakat Desa Panyingkiran menjadi memiliki keterampilan dalam mengolah limbah jambu biji merah, hal ini terlihat dari aktivitas di kebun yang lebih bersih dan lingkungan kebun terlihat tampak tertata dan lebih bersih, saluran air dan sanitasi kingkungan menjadi berfungsi kembali hal ini berdampak hilangnya bau yang ditimbulkan dari limbah jambu biji merah yang ditumpuk sehingga lingkungan kebun jambu biji merah dan lingkungan Desa Panyingkiran menjadi lebih nyaman dan terjadinya sinergitas antara keluarga petani, pengepul, pedagang, dan masyarakat dalam menciptakan kondisi rumah tangga dan kebun yang nyaman. 


\section{Kesimpulan}

Mitra mendapatkan keterampilan dalam memanfaatkan limbah jambu biji merah menjadi MOL sebagai bioaktivator. Bioaktivator dimanfaatkan untuk mempercepat proses pengolahan dan pengomposan sampah organic sebagai starter dengan waktu pengomposan relatif singkat yaitu 14 hari.

\section{Daftar Pustaka}

Aristanti, A., \& Widyastuti, N. (2016). PENGARUH PEMBERIAN JUS JAMBU BIJI MERAH (Psidium Guajava L.) TERHADAP KADAR GLUKOSA DARAH PADA ATLET SEPAKBOLA USIA 16-18 TAHUN. Journal of Nutrition College. https://doi.org/10.14710/jnc.v5i4.16462

Diana, Y., Mulyono, G. P. E., Syarief, O., Mutiyani, M., \& Sukmawati, S. (2019). Peranan Jus Jambu Biji Merah Terhadap Kadar Asam Urat Pada Penderita Hiperurisemia. Jurnal Riset Kesehatan Poltekkes Depkes Bandung.

Gandu, I. V., Budiarso, F. D. H., Kepel, B. J., Fatimawali, ., Manampiring, A., \& Bodhi, W. (2021). Molecular Docking Senyawa Asam Askorbat dan Kuersetin pada Tumbuhan Jambu Biji Merah (Psidium guajava L.) Sebagai Pencegah COVID-19. Jurnal E-Biomedik. https://doi.org/10.35790/ebm.v9i2.31846

Hadi, R. A. (2019). PEMANFAATAN MOL (MIKROORGANISME LOKAL) DARI MATERI YANG TERSEDIA DI SEKITAR LINGKUNGAN. AGROSCIENCE (AGSCI). https://doi.org/10.35194/agsci.v9i1.637

Handayani, S. H., Yunus, A., Susilowati, A. (2015). Uji Kualitas Pupuk Organik Cair dari Berbagai Macam Mikroorganisme Lokal (MOL). Jurnal EL-VIVO.

Imanudin, O., \& Widianingrum, D. (2018). Biokonversi Feses Ayam Broiler yang diberi Ransum Mengandung Limbah Jambu Biji Merah sebagai Feed Additive. Jurnal Peternakan Indonesia (Indonesian Journal of Animal Science). https://doi.org/10.25077/jpi.20.1.42-51.2018

Jumali. (2017). Pemanfaatan Mikroorganisme Lokal Bonggol Pisang Sebagai Starter Kompos Campuran Feses Sapi Dan Kulit Pinang Terhadap Kualitas Kompos Serta Pertumbuhan Rumput Gajah (Pennisetum Purpureum). Program Studi Magister IImu Peternakan Pasca Sarjana Universitas Jambi.

Kurniawan, A. (2018). Mol Production (Local Microorganisms) With Organic Ingredients Utilization Around. Jurnal Hexagro.

Padang, S. A., \& Maliku, R. M. (2019). PENETAPAN KADAR VITAMIN C PADA BUAH JAMBU BIJI MERAH (Psidium guajava L.) DENGAN METODE TITRASI NA-2,6 DICHLOROPHENOL INDOPHENOL (DCIP). Media Farmasi. https://doi.org/10.32382/mf.v13i2.879

Rahayuningrum, D. C., \& Morika, H. D. (2019). Pengaruh kosumsi Jus Jambu Biji Merah Terhadap Peningkatan Kadar Trombosit Pada Pasien Demam Berdarah Dengue (DBD). Jurnal Kesehatan Saintika Meditory.

Rusdi, P. H. N. (2020). Pengaruh Pemberian Jus Jambu Biji Merah (Psidium Guajava.L) Terhadap Kadar Hemoglobin Penderita Anemia Remaja Putri. Human Care Journal.

Sultoni, Miswan, \& R.A.C.Nur. (2019). Efektifitas Mikroorganisme Lokal (Mol) Limbah Nasi Sebagai Aktif Ator Pembuatan Pupuk Kompos Organik. Jurnal Kolaboratif Sains.

Widianingrum, D., Somanjaya, R., \& Oki, D. A. N. (2019). PENGARUH PENAMBAHAN MOL JAMBU BIJI MERAH (Psidium guajava L.) SEBAGAI BIOSTARTER TERHADAP KUALITAS FERMENTASI LIMBAH IKAN LELE (Clarias sp). Jurnal Ilmu Pertanian Dan Peternakan.

Wisnu, V. (2020). PEMANFAATAN LIMBAH ISI RUMEN SAPI SEBAGAI MIKROORGANISME LOKAL (MOL). Jurnal ATMOSPHERE. https://doi.org/10.36040/atmosphere.v1i1.2958 